\title{
Habitat use by post-fledging white-tailed eagles shows avoidance of human infrastructure and agricultural areas
}

\author{
Fabio Balotari-Chiebao ${ }^{1}$ (D) $\cdot$ Jon E. Brommer ${ }^{1} \cdot$ Hannu Tikkanen ${ }^{2} \cdot$ Toni Laaksonen $^{1}$ \\ Received: 13 October 2020 / Revised: 25 January 2021 / Accepted: 25 March 2021 / Published online: 12 April 2021 \\ (C) The Author(s) 2021
}

\begin{abstract}
Habitat use studies provide invaluable information for the conservation of species that suffer from habitat loss or degradation. We used satellite telemetry to study the habitat use of white-tailed eagles (Haliaeetus albicilla) in relation to six habitat classes (artificial surfaces, agricultural areas, forests, semi-natural areas, wetlands and waterbodies) and five forest age classes $(0-9,10$ 19, 20-59, 60-99 and $\geq 100$ years old) during the post-fledging period in Finland. The post-fledging period, defined here as the period between fledging and dispersal from the natal area, is a critical life-history stage. Our primary objective was to provide information that could be integrated into landscape planning, including wind-energy development (which poses a threat to whitetailed eagles). We found that the habitat classes that were selected by the young white-tailed eagles were forests, semi-natural areas (i.e., transitional woodland and bare rock) and wetlands. When using forests, the eagles selected stands of 0-9 years old, presumably due to the use of retention trees surrounded by a clear-cut as perching sites. Conversely, the habitat classes that were avoided were artificial surfaces, agricultural areas and (the immediate vicinity of) waterbodies. We conclude that the conversion of natural habitats into built and agricultural areas is detrimental to young white-tailed eagles because it reduces habitat availability. They, however, appear to be capable of using forests recently impacted by forestry if perch trees are present. Careful landscape planning is needed to protect priority habitats and avoid conflicts with an expanding white-tailed eagle population (e.g., by building wind farms in areas already environmentally disturbed).
\end{abstract}

Keywords Raptor $\cdot$ Spatial ecology $\cdot$ Selection ratios $\cdot$ Land use $\cdot$ Conservation

\section{Introduction}

Land-use change poses a major threat to biodiversity and population viability worldwide (Sala et al. 2000). In particular, habitat loss or degradation driven by agricultural intensification, deforestation and infrastructure development is associated with a growing number of threatened species within higher taxa (Mace et al. 2005; Baillie et al. 2010; Pereira et al. 2010; Pimm et al. 2014). The conservation of a target species can thus benefit from an understanding of its space use, habitat requirements and the relative importance of local resources (Manly et al. 2002).

Fabio Balotari-Chiebao fabiobalotari@hotmail.com

1 Section of Ecology, Department of Biology, University of Turku, FI-20014 Turku, Finland

2 Ecology and Genetics Research Unit, University of Oulu, P.O. Box 3000, 90014 Oulu, Finland
Raptors are easily subject to disturbance and often depend on large hunting areas (Hardey et al. 2013). Raptors are vulnerable to the loss or degradation of natural habitats (Bildstein et al. 1998; Herremans and Herremans-Tonnoeyr 2000; Kirby et al. 2008) and can be significantly stressed and thus negatively affected by human infrastructure (e.g., roads and paths; Krone et al. 2019). Some species, such as the peregrine falcon (Falco peregrinus), the tawny owl (Strix aluco) and the American kestrel (Falco sparverius), have shown to be adaptable to urbanisation (Chace and Walsh 2006). However, many raptor species across the world have an unfavourable conservation status or a declining trend (McClure et al. 2018), thus requiring protection of breeding and foraging habitats (Suárez et al. 2000; Balbontín 2005; Tanferna et al. 2013; Rivers et al. 2014). The white-tailed eagle is a large, diurnal raptor with a history of population declines. In the 1960s and 1970s, its numbers declined dramatically as a result of widespread environmental pollution (Cramp and Simmons 1980), notably around the Baltic Sea (HELCOM 2018). Following the ban of harmful bio-accumulating substances (HELCOM 2018), 
the species has recovered significantly in the last decades and has been downlisted from vulnerable (VU) to least concern (LC) in the Finnish Red List (Hyvärinen et al. 2019). However, the white-tailed eagle still faces a range of threats and limiting factors over its vast geographical distribution and is listed in Annex I of the EU's Birds Directive (Directive 2009/147/EC 2009). At present, notable pressures include lead poisoning (Isomursu et al. 2018) and habitat loss or degradation in the form of forestry, land exploitation, river regulation and wetland drainage (Helander and Stjernberg 2002; Probst and Gaborik 2011).

Some studies of white-tailed eagles have focused on nestsite selection. These include nest-site selection in reintroduced (Evans et al. 2010), naturally returning (Treinys et al. 2016) and recovering populations (Radović and Mikuska 2009; Sándor et al. 2015). Other studies have focused on individual movements with high-precision telemetry data to study home ranges and habitat use (Scholz 2010; Krone et al. 2013; May et al. 2013; Balotari-Chiebao et al. 2016a; Bragin et al. 2018). However, the post-fledging period, defined as the period between fledging and dispersal from the natal area (Morrison and Wood 2009), has generally received less attention. The post-fledging period is a critical life-history stage, for it is when young birds enhance muscular development, begin to explore the surroundings, interact with conspecifics and acquire crucial foraging skills for later survival (Delgado et al. 2009). During this period, white-tailed eagles lack flight experience and manoeuvrability and are also more naïve towards the environment (Bevanger et al. 2010). In the case of wind farms, this may increase collision risk (May et al. 2011; May et al. 2013; Krone and Treu 2018). Also, it appears that collision fatalities do not show an age bias (when the age composition of a population is taking into account), meaning that juveniles may be equally in danger as, e.g. adults (Heuck et al. 2020), which often collide in greater numbers. Windfarm fatalities are a concern for white-tailed eagles (Krone and Scharnweber 2003; Dahl et al. 2012; Kitano and Shiraki 2013) and other large soaring raptors (Barrios and Rodríguez 2004; Smallwood and Thelander 2008).

In white-tailed eagles, post-fledging parental dependency decreases gradually over $c a$. 35-40 days (Cramp and Simmons 1980) or longer (Hardey et al. 2013). Dispersal from the natal area occurs in their first year of life, usually between September and January (Hardey et al. 2013; Balotari-Chiebao et al. 2016a). Here, we use high-precision telemetry data to study the movements of Finnish white-tailed eagles during the post-fledging period. We examine their habitat use in relation to six habitat classes and five forest age classes, discussing their ecological relevance for landscape planning. We provide general recommendations for wind-energy planners, given the interests in building wind farms particularly along the coast (Finnish Wind Power Association 2020) and the growing concern about negative impacts of wind turbine collisions on the white-tailed eagle population (Balotari-Chiebao et al. 2016b; Tikkanen et al. 2018).

\section{Materials and methods}

\section{Satellite telemetry}

In 2009-2011 and 2013, a total of 14 white-tailed eagles nestlings from 13 nests were equipped with a $70 \mathrm{~g}$ Argos/GPS Solar Powered PTT (Platform Transmitter Terminal; Microwave Telemetry, Inc.). The satellite tags were placed as a backpack with a Teflon harness. They were programmed to transmit fixes at 1-hour intervals during daytime, with a decreasing number of fixes as the length of day became shorter. The total weight carried by an eaglet at the time of fitting $(\sim 100 \mathrm{~g}$, including an additional battery for data collection during the winter) complied with recommendations on loading (Kenward 2001). Permission for ringing and satellite tagging was issued by the Centre for Economic Development, Transport and the Environment (ELY) of Finland.

\section{Study period}

Our study focused on the post-fledging period, that is, the period between fledging and dispersal from the natal area. Here, fledging was assumed to have occurred when an eagle's distance to the nest was at least twice as long as the average location error ( $10 \mathrm{~m}$; Balotari-Chiebao et al. (2016a)) for $\geq 5$ consecutive relocations. Dispersal was assumed to have occurred when an eagle stayed $\geq 5 \mathrm{~km}$ away from the nest for $\geq$ 10 consecutive days. Data collected during the study period $(\bar{x}$ $=85$ days $\pm 31 \mathrm{SD}$, range $=37-164$ days, $n=14$ ) amounted to 11,171 observations $(\bar{x}=798 \pm 308 \mathrm{SD}, n=14)$. In-flight positions were $c .4 \%$ of total observations.

\section{Study areas}

We established our study areas based on the home ranges of the satellite-tracked eagles. Firstly, home ranges were estimated using a normal bivariate Kernel Density Estimator (KDE) with $95 \%$ probability contours (Worton 1989), with default settings in the kernelUD function from the $\mathrm{R}$ package adehabitatHR (Calenge 2006). Secondly, we identified for each eagle the outermost location relative to the nest that fell inside its home range (95\% kernel-based home range size: $\bar{x}=$ $7.83 \mathrm{~km}^{2} \pm 6.66 \mathrm{SD}, n=14$; outermost location: $\bar{x}=3.6 \mathrm{~km} \pm$ $1.1 \mathrm{SD}, n=14)$. We then used this location to draw a circle centred on the nest. These resulting circular areas were our study areas. Further details on the space use and ranging behaviour of the study eagles can be found in Balotari-Chiebao et al. (2016a). 
Our study areas were located in the Alland Islands and the coastal regions of Southwest Finland, Satakunta and Ostrobothnia (Fig. 1). Altogether they covered $620 \mathrm{~km}^{2}$ of mostly waterbodies (the Baltic Sea and lakes) and coniferous and mixed forests, with tracts of transitional woodland and agricultural areas (Table 1). They were all fragmented by roads, particularly gravel roads. Only a small proportion of the forests were $\geq 100$ years old $(\sim 7 \%)$, reflecting the widespread impact of commercial forestry on old-growth trees (Kontula and Raunio 2018). The terrain was generally flat, with no elevation higher than $60 \mathrm{~m}$ above sea level.

\section{Spatial datasets}

We used CORINE Land Cover 2012 (20-m resolution; Finnish Environment Institute 2014) to obtain information on Finland's national land cover. The CORINE dataset consisted of 48 habitat classes arranged in four hierarchical levels. For the analysis, we grouped the habitats present in our study areas into six large classes: (I) artificial surfaces, (II) agricultural areas, (III) forests, (IV) semi-natural areas, (V) wetlands and (VI) waterbodies (Table 1). The Baltic Sea and lakes were treated as a single class (i.e. waterbodies), as the latter were present at a highly variable amount in the study areas $(\bar{x}=4.8 \% \pm 15.4 \mathrm{SD}$; range $=0-58.1 \%)$. In addition, we used the topographic database from the National Land Survey (NLS) of Finland to extract roads (paved and unpaved). The road layer was rasterised, with the same resolution as the CORINE dataset, to produce a binary image indicating which pixels were occupied by a road. The road pixels were then classified as artificial surfaces and incorporated into the CORINE dataset (Table 1). To obtain information on forest age, we relied on the Multi-Source National Forest Inventory (MS-NFI) produced by the Natural Resources Institute Finland (Luke). Forest age inventories were available at two resolutions (16 $\mathrm{m}$ and $20 \mathrm{~m}$ ) for three different years (2009, 2011 and 2013). To ensure matching origin and resolution between these raster layers, we adjusted the pixel size of the $16-\mathrm{m}$ inventory to a $20-\mathrm{m}$ resolution by resampling with the bilinear method (Wegmann et al. 2016). We used all three inventories in an effort to match the available forest age information with the study period (see Section 2.1). Following



Fig. 1 Approximate nest site locations of the study white-tailed eagles. The dashed circle is used to indicate an area containing five nests that are closely separated from each other,and therefore difficult to visualise at the used scale 
Table 1 Detailed composition of all habitats that were present in our study areas, presented here in two hierarchical levels. The relative proportion of each habitat class is given within parentheses

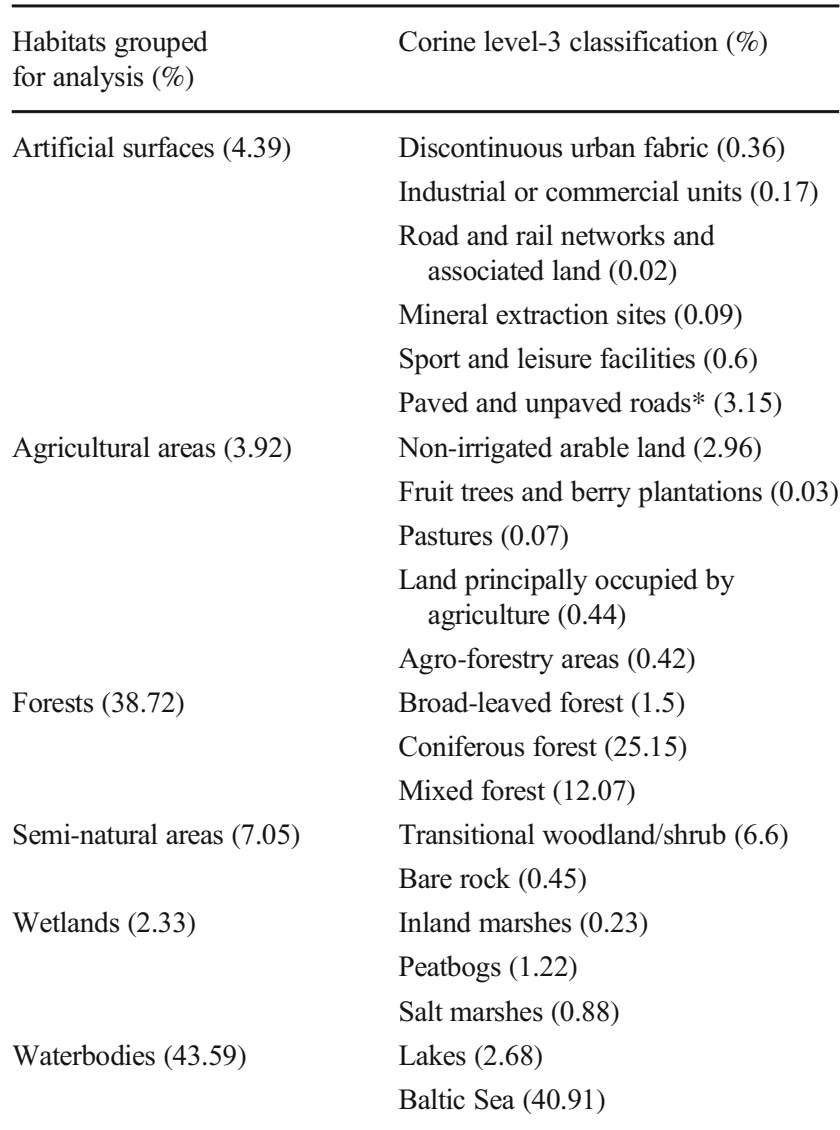

*Extracted from the NLS topographic database and incorporated into the Corine dataset (see the "Study areas" section for details).

Sandgren et al. (2014), we then divided forest age into five classes: (I) 0-9, (II) 10-19, (III) 20-59, (IV) 60-99 and (V) $\geq$ 100 years old. We used R (version 4.0.2; R Core Team 2020) for data analysis and as a geographic information system (GIS) for handling and processing all spatial datasets.

\section{Habitat use}

We analysed habitat use via the estimation of selection ratios. This approach is appropriate when resource units (e.g. the pixels in a raster) can be classified into one of several categories (e.g. habitat classes; Manly et al. 2002). Habitat use is considered to be selective when a resource category is used disproportionately to its availability. Here, use and availability were quantified separately for each eagle (Design III as classified by Thomas and Taylor (1990)), as our satellite-tracked eagles were uniquely identified. For use, we calculated the number of resource units per habitat and forest age classes within a 30-m buffer added to each position. We deemed this buffer size sufficiently large to account for habitat misclassification due to locational error $(\sim 10 \mathrm{~m})$. For availability, we calculated the number of resource units based on the relative proportion of habitat and forest age classes in the study areas. We then used the following estimator to obtain the selection ratios (Manly et al. 2002):

$\widehat{w}_{i}={ }^{u_{i+}} / \sum_{j=1}^{n} \pi_{i j} u_{+j}$

where $\mathrm{u}_{\mathrm{i}+}$ is the total number of used resource units in category $i, \pi_{\mathrm{ij}}$ the proportion of resources available to eagle $j$ in category $i$ and $u_{+\mathrm{j}}$ the total number of used resource units by eagle $j$. A selection ratio $>1$ indicates selection, while $<1$ indicates avoidance (Manly et al. 2002).

\section{Addressing spatial and temporal autocorrelation}

Spatial and temporal autocorrelation are a common difficulty in spatial data analysis, because they violate the assumption of independence of observations. Spatial and temporal autocorrelation decrease as the time interval between animal relocations is increased (Thomas and Taylor 2006). Based on this rationale, we increased the location-time interval by randomly sampling one observation per day per eagle. We applied the Durbin-Watson test (implemented with the $d w t e s t$ function from the R package lmtest; Zeileis and Hothorn 2002) to ensure that this location-time interval was appropriate to treat autocorrelation. To avoid unequal sample sizes, the number of observations per eagle was further reduced to 38 , which is the minimum number of successfully tracking days among all eagles $(\bar{x}=78 \pm 25 \mathrm{SD}$, range $=38-139, n=14)$. Given such a reduction of the original dataset, we performed the random sampling ( 1 observation per day, totalling 38 observations per eagle) 1000 times for a thorough exploration of the available data. Confidence intervals for the selection ratios corresponded to the $2.5 \%$ lower and upper quantiles.

\section{Results}

The post-fledging period ranged from 20 June (the earliest fledging) to 23 December (latest onset of dispersal). Nestlings fledged at $71-86$ days old $(\bar{x}=79 \pm 4$ SD) and juveniles dispersed at $115-244$ days old $(\bar{x}=164 \pm 31 \mathrm{SD})$. The post-fledging white-tailed eagles showed selection for forests, semi-natural areas and wetlands. Semi-natural areas, which in our study areas were mostly composed of transitional woodland/shrub (Table 1), were the habitat class with the highest selection ratio (Fig. 2a). Conversely, the eagles avoided artificial surfaces, agricultural areas and waterbodies. The avoidance of waterbodies, a major foraging habitat for the species, was expected given the small proportion of in-flight positions (c. $4 \%$ ) and the subsampling of the data (1 observation/day/eagle). When using forests, they selected (though with a marginal significance) young patches between 0 and 

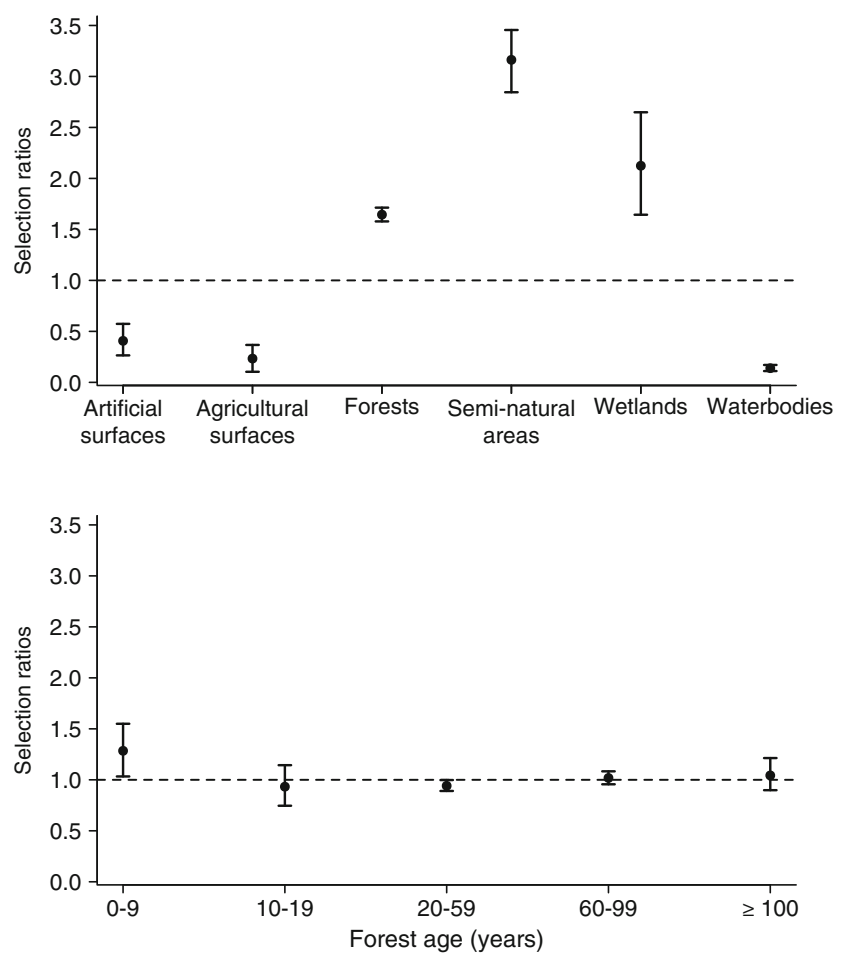

Fig. 2 Selection ratios for different habitat and forest age classes for white-tailed eagles during the post-fledging period. Values above the dashed line indicate selection, whereas values below the dashed line indicate avoidance. The points are median estimates from the analysis of 1000 randomised datasets. Confidence intervals correspond to the $2.5 \%$ lower and upper quantiles (see the "Habitat use" section for details)

9 years old. All the other forest age classes were used in proportion to their availability (Fig. $2 b$ ).

\section{Discussion}

We studied the habitat use of white-tailed eagles during the post-fledging period in the west and southwest of Finland, primarily in coastal areas. Our study highlights the selection of forests $(0-9$ years old), semi-natural areas and wetlands. It also highlights the avoidance of artificial surfaces, agricultural areas and waterbodies. This pattern gives clear indication that the loss or alteration of natural habitats (resulting from the development of various types of artificial surfaces and agricultural areas) reduces habitat availability to post-fledging white-tailed eagles.

Sandgren et al. (2014) showed that post-fledging golden eagles in Swedish Lapland favoured forests of the same age class that was selected here by white-tailed eagles and related such selection to prey availability. In our case, given the differences in the feeding ecology of the two species, the selection of young forests may be explained by the use of retention trees as perching sites. Green tree retention (GTR) is a forestry practice applied to boreal forest management, with a retention of normally 5-10 trees/ha in Fennoscandia (Vanha-Majamaa and Jalonen 2001). Retention trees are surrounded by clear-cut areas and provide the eagles with a largely unobstructed view and sufficient space for flying. The selective use of young forests thus suggests that post-fledging white-tailed eagles are capable of using an environment recently impacted by forestry (as long as there are perch trees).

Artificial surfaces and agricultural areas were clearly avoided by the eagles. These results are in line with previous satellite-tracking studies of adult (Scholz 2010) and sub-adult white-tailed eagles (May et al. 2013). It is worth adding that construction and land clearing for agricultural purposes are major threats to various habitat types in Finland, leading to negative consequences for associated taxa (Kontula and Raunio 2018). Waterbodies (the other avoided habitat class) were abundant in the study areas, but they were used less than expected from their availability. As revealed by the $30-\mathrm{m}$ buffer (used here to assess the habitats that were in the immediate vicinity of the observed positions), the eagles tended not to be in close proximity with waterbodies (or e.g. sitting on skerries). The relatively small proportion of in-flight positions (c. $4 \%$ ) may have contributed to overestimate of the avoidance of waterbodies.

Wind energy poses a new threat to white-tailed eagles, which are known to be vulnerable to collision mortality (Dahl et al. 2012). In Finland at least 20 white-tailed eagles, including juveniles, have been found dead and reported by the general public since 2005 (T. Stjernberg, pers. comm., 17 March 2020). A lack of long-term, systematic carcass searches prevents an understanding of the impact of this type of fatality on the population. Finland's installed wind-energy capacity is currently modest (754 turbines produced $7 \%[5.9 \mathrm{TWh}]$ of its electricity consumption in 2019; Finnish Wind Power Association 2020), but it will continue to increase in the near future (Huttunen 2017). The threats posed by future wind farms, which will help to reach the goal of 7-9 TWh of wind-derived electricity by 2030 (Huttunen 2017), will largely depend on site selection (Meller 2017). Siting wind farms away from important habitats and in areas already environmentally disturbed would presumably reduce the likelihood of conflicts with white-tailed eagles. We note, however, that simply siting wind farms where raptors are less abundant does not necessarily minimise fatalities (De Lucas et al. 2008), as collision mortality depends on a range of factors, including species, topography and wind-farm specifications.

\section{Management implications}

The conversion of natural habitats into built and agricultural areas reduces the availability of suitable habitats to whitetailed eagles during the post-fledging period. Conversely, the protection of forests, semi-natural areas and wetlands would benefit them during this critical life-history stage. As regards 
wind energy, to reduce the likelihood of conflicts, wind farms should be sited away from important habitats and in areas that are already environmentally disturbed (e.g., agricultural areas). This precautionary measure, combined with other mitigation strategies (e.g., wind-farm configuration), would presumably reduce the risk of collision among young white-tailed eagles and possibly among adult white-tailed eagles. This is particularly important for coastal areas, as most of the existing, planned and proposed Finnish wind farms are located on the coast, and the presence of breeding white-tailed eagles is significant.

Funding Open access funding provided by University of Turku (UTU) including Turku University Central Hospital.

Open Access This article is licensed under a Creative Commons Attribution 4.0 International License, which permits use, sharing, adaptation, distribution and reproduction in any medium or format, as long as you give appropriate credit to the original author(s) and the source, provide a link to the Creative Commons licence, and indicate if changes were made. The images or other third party material in this article are included in the article's Creative Commons licence, unless indicated otherwise in a credit line to the material. If material is not included in the article's Creative Commons licence and your intended use is not permitted by statutory regulation or exceeds the permitted use, you will need to obtain permission directly from the copyright holder. To view a copy of this licence, visit http://creativecommons.org/licenses/by/4.0/.

\section{References}

Baillie JEM, Griffiths J, Turvey ST, Loh J, Collen B (2010) Evolution lost: Status and Trends of the World's Vertebrates. Zoological Society of London, United Kingdom

Balbontín J (2005) Identifying suitable habitat for dispersal in Bonelli's eagle: An important issue in halting its decline in Europe. Biol Conserv 126:74-83

Balotari-Chiebao F, Villers A, Ijäs A, Ovaskainen O, Repka S, Laaksonen T (2016a) Post-fledging movements of white-tailed eagles: Conservation implications for wind-energy development. Ambio 45:831-840

Balotari-Chiebao F, Brommer JE, Niinimäki T, Laaksonen T (2016b) Proximity to wind-power plants reduces the breeding success of the white-tailed eagle. Anim Conserv 19:265-272

Barrios L, Rodríguez A (2004) Behavioural and environmental correlates of soaring-bird mortality at on-shore wind turbines. J Appl Ecol 41: $72-81$

Bevanger K, Berntsen F, Clausen S, Dahl EL, Flagstad Ø, Follestad A, Halley D, Hanssen F et al (2010) Pre- and post-construction studies of conflicts between birds and wind turbines in coastal Norway (Bird-Wind). 620. NINA Report. Trondheim, Norway

Bildstein KL, Schelsky W, Zalles J (1998) Conservation status of tropical raptors. J Raptor Res 32:3-18

Bragin E, Poessel S, Lanzone M, Katzner T (2018) Post-fledging movements and habitat associations of White-tailed Sea Eagles (Haliaeetus albicilla) in Central Asia. Wilson J Ornithol 130:784788
Calenge C (2006) The package adehabitat for the R software: a tool for the analysis of space and habitat use by animals. Ecol Model 197: 516-519

Chace JF, Walsh JJ (2006) Urban effects on native avifauna: a review. Landsc Urban Plan 74:46-69

Cramp S, Simmons KEL (1980) Handbook of the Birds of Europe, the Middle East and North Africa: Hawks to Bustards, vol II. Oxford University Press, Oxford, UK

Dahl EL, Bevanger K, Nygård T, Røskaft E, Stokke BG (2012) Reduced breeding success in white-tailed eagles at Smøla windfarm, western Norway, is caused by mortality and displacement. Biol Conserv 145:79-85

De Lucas M, Janss GFE, Whitfield DP, Ferrer M (2008) Collision fatality of raptors in wind farms does not depend on raptor abundance. $\mathrm{J}$ Appl Ecol 45:1695-1703

Delgado M d M, Penteriani V, Nams VO (2009) How Fledglings Explore Surroundings from Fledging to Dispersal. A Case Study with Eagle Owls Bubo bubo. Ardea 97:7-15

Directive 2009/147/EC (2009) DIRECTIVE 2009/147/EC of the European Parliament and of the Council on the conservation of wild birds

Evans RJ, Pearce-Higgins J, Whitfield DP, Grant JR, MacLennan A, Reid R (2010) Comparative nest habitat characteristics of sympatric White-tailed Haliaeetus albicilla and Golden Eagles Aquila chrysaetos in western Scotland. Bird Study 57:473-482

Finnish Environment Institute (2014) Corine Land Cover 2012. https:// www.syke.fi/en-US. Accessed 22 Apr 2020

Finnish Wind Power Association (2020) Wind power projects in Finland. https://tuulivoimayhdistys.fi/. Accessed on 01/07/2020

Hardey J, Crick H, Wernham C, Riley H, Etheridge B, Thompson D (2013) Raptors: a field guide to survey and monitoring. Norfolk, TSO (The Stationery Office)

Helander B, Stjernberg T (2002) Action Plan for the conservation of White-tailed Sea Eagle (Haliaeetus albicilla). Prepared on behalf of BirdLife International Sweden. Convention on the Conservation of European Wildlife and Natural Habitats, Strasbourg, France

HELCOM (2018) HELCOM White-tailed sea eagle productivity. HELCOM Core Indicator Report. Online.

Herremans M, Herremans-Tonnoeyr D (2000) Land use and the conservation status of raptors in Botswana. Biol Conserv 94:31-41

Heuck C, Herrmann C, Wendt J, Krone O, Brandl R, Albrecht J (2020) Sex- but not age-biased wind turbine collision mortality in the White-tailed Eagle Haliaeetus albicilla. J Ornithol 161:753-757

Huttunen R (2017) Government report on the National Energy and Climate Strategy for 2030. Publications of the Ministry of Economic Affairs and Employment. Ministry of Economic Affairs and Employment, Helsinki

Hyvärinen E, Juslén A, Kemppainen E, Uddström A, Liukko UM (2019) The 2019 Red List of Finnish Species [English summary]. Helsinki, Ympäristöministeriö \& Suomen ympäristökeskus

Isomursu M, Koivusaari J, Stjernberg T, Hirvelä-Koski V, Venäläinen ER (2018) Lead poisoning and other human-related factors cause significant mortality in white-tailed eagles. Ambio 47:858-868

Kenward RE (2001) A manual for wildlife radio tagging. Academic Press, London

Kirby JF, Stattersfield AJ, Butchart SHM, Evans MI (2008) Key conservation issues for migratory land- and waterbird species on the world's major flyways. Bird Conserv Int 18:S49-S73

Kitano M, Shiraki S (2013) Estimation of bird fatalities at wind farms with complex topography and vegetation in Hokkaido, Japan. Wildl Soc Bull 37:41-48

Kontula T, Raunio A (2018) Suomen luontotyyppien uhanalaisuus 2018. Luontotyyppien punainen kirja - Osa 1: Tulokset ja arvioinnin perusteet [Summary in English]. 5/2018. Suomen Ympäristö. Helsinki: Suomen ympäristökeskus ja ympäristöministeriö 
Krone O, Scharnweber C (2003) Two white-tailed sea eagles (Haliaeetus albicilla) collide with wind generators in northern Germany. Raptor 174:174-176

Krone O, Treu G (2018) Movement patterns of white-tailed sea eagles near wind turbines. J Wildl Manag 82:1367-1375

Krone O, Nadjafzadeh M, Berger A (2013) White-tailed Sea Eagles (Haliaeetus albicilla) defend small home ranges in north-east Germany throughout the year. J Ornithol 154:827-835

Krone O, Bailey LD, Jähnig S, Lauth T, Dehnhard M (2019) Monitoring corticoid metabolites in urine of white-tailed sea eagles: Negative effects of road proximity on breeding pairs. Gen Comp Endocrinol 283:113223

Mace GM, Masundire H, Baillie JEM (2005) Biodiversity. In: Ecosystems and Human Well-being: Current State and Trends, Volume 1. The Millennium Ecosystem Assessment Series. Island Press, Washington D.C.

Manly BFJ, McDonald LL, Thomas DL, McDonald TL, Erickson WP (2002) Resource selection by animals: statistical analysis and design for field studies. Kluwer, Nordrecht, The Netherlands

May R, Nygård T, Dahl EL, Reitan O, Bevanger K (2011) Collision risk in white-tailed eagles: Modelling kernel-based collision risk using satellite telemetry data in Smøla wind-power plant. 692. NINA Report

May R, Nygård T, Dahl EL, Bevanger K (2013) Habitat utilization in white-tailed eagles (Haliaeetus albicilla) and the displacement impact of the Smøla wind-power plant. Wildl Soc Bull 37:75-83

McClure CJW, Westrip JRS, Johnson JA, Schulwitz SE, Virani MZ, Davies R, Symes A, Wheatley H, Thorstrom R, Amar A, Buij R, Jones VR, Williams NP, Buechley ER, Butchart SHM (2018) State of the world's raptors: Distributions, threats, and conservation recommendations. Biol Conserv 227:390-402

Meller K (2017) Impact of wind turbines on avifauna and bats in literature and reports [English summary]. 27. Publications of the Ministry of Economic Affairs and Employment

Morrison JL, Wood PB (2009) Broadening our approaches to studying dispersal in raptors. Raptor 43:81-89

Pereira HM, Leadley PW, Proença V, Alkemade R, Scharlemann JPW, Fernandez-Manjarrés JF, Araújo MB, Balvanera P, Biggs R, Cheung WWL, Chini L, Cooper HD, Gilman EL, Guénette S, Hurtt GC, Huntington HP, Mace GM, Oberdorff T, Revenga C, Rodrigues P, Scholes RJ, Sumaila UR, Walpole M (2010) Scenarios for Global Biodiversity in the $21^{\text {st }}$ Century. Science 330: 1496-1501

Pimm SL, Jenkins CN, Abell R, Brooks TM, Gittleman JL, Joppa LN, Raven PH, Roberts CM et al (2014) The biodiversity of species and their rates of extinction, distribution, and protection. Science 344: 987-997

Probst R, Gaborik A (2011) Action plan for the conservation of the whitetailed eagle (Haliaeetus albicilla) along the Danube. Convention on the Conservation of European Wildlife and Natural Habitats, Strasbourg, France

R Core Team (2020) R: A Language and Environment for Statistical Computing. R Foundation for statistical computing, Vienna, Austria
Radović A, Mikuska T (2009) Population size, distribution and habitat selection of the white-tailed eagle Haliaeetus albicilla in the alluvial wetlands of Croatia. Biologia 64:156-164

Rivers JW, Johnson JM, Haig SM, Schwarz CJ, Glendening JW, Burnett LJ, George D, Grantham J (2014) Resource Selection by the California Condor (Gymnogyps californianus) Relative to Terrestrial-Based Habitats and Meteorological Conditions. PLoS One 9:e88430

Sala OE, Stuart Chapin F III, Armesto JJ, Berlow E, Bloomfield J, Dirzo R, Huber-Sanwald E et al (2000) Global Biodiversity Scenarios for the Year 2100. Science 287:1770-1774

Sandgren C, Hipkiss T, Dettki H, Ecke F, Hörnfeldt B (2014) Habitat use and ranging behaviour of juvenile Golden Eagles Aquila chrysaetos within natal home ranges in boreal Sweden. Bird Study 61:9-16

Sándor AD, Alexe V, Marinov M, Doroșencu A, Domsa C, Kiss BJ (2015) Nest-site selection, breeding success, and diet of whitetailed eagles (Haliaeetus albicilla) in the Danube Delta, Romania. Turk J Zool 39:300-307

Scholz F (2010) Spatial use and habitat selection of white-tailed eagles (Haliaeetus albicilla) in northern Germany. PhD Thesis, Berlin: Freie Universität Berlin

Smallwood KS, Thelander C (2008) Bird Mortality in the Altamont Pass Wind Resource Area, California. J Wildl Manag 72:215-223

Suárez S, Balbontín J, Ferrer M (2000) Nesting Habitat Selection by Booted Eagles Hieraaetus pennatus and Implications for Management. J Appl Ecol 37:215-223

Tanferna A, López-Jiménez L, Blas J, Hiraldo F, Sergio F (2013) Habitat selection by Black kite breeders and floaters: Implications for conservation management of raptor floaters. Biol Conserv 160:1-9

Thomas DL, Taylor EJ (1990) Study Designs and Tests for Comparing Resource Use and Availability. J Wild1 Manag 54:322-330

Thomas DL, Taylor EJ (2006) Study Designs and Tests for Comparing Resource Use and Availability II. J Wildl Manag 70:324-336

Tikkanen H, Balotari-Chiebao F, Laaksonen T, Pakanen V-M, Rytkönen S (2018) Habitat use of flying subadult White-tailed Eagles (Haliaeetus albicilla): implications for land use and wind power plant planning. Ornis Fenn 95:137-150

Treinys R, Dementavičius D, Rumbutis S, Švažas S, Butkauskas D, Sruoga A, Dagys M (2016) Settlement, habitat preference, reproduction, and genetic diversity in recovering the white-tailed eagle Haliaeetus albicilla population. J Ornithol 157:311-323

Vanha-Majamaa I, Jalonen J (2001) Green Tree Retention in Fennoscandian Forestry. Scand J For Res 16:79-90

Wegmann M, Leutner B, Dech S (2016) Remote Sensing and GIS for Ecologists. Pelagic Publishing

Worton BJ (1989) Kernel Methods for Estimating the Utilization Distribution in Home-Range Studies. Ecology 70:164-168

Zeileis A, Hothorn T (2002) Diagnostic Checking in Regression Relationships. R News 2:7-10

Publisher's note Springer Nature remains neutral with regard to jurisdictional claims in published maps and institutional affiliations. 